\title{
BISINDO SIGN LANGUAGE TRANSLITERATION USING AUTOMATA
}

\author{
Awang Hendrianto Pratomo ${ }^{1}$, Oliver S. Simanjuntak ${ }^{2}$, Dimas Candra Nugraha Putra ${ }^{3}$ \\ ${ }^{\mathbf{1 , 2 , 3}}$ Program Studi Teknik Informatika, Fakultas Teknik Industri, \\ Universitas Pembangunan Nasional "Veteran" Yogyakarta \\ Jl. Babarsari No.2, Tambak Bayan, Depok, Sleman, Yogyakarta, 55281. \\ Email : ${ }^{1}$ awang@upnyk.ac.id, ${ }^{2}$ oliversimanjuntak@yahoo.com, \\ dimas.chandra169@gmail.com
}

\begin{abstract}
Sign Language is a language which prioritizes manual communication, body language and lip movement for communication. People who usesign language for communication aredeaf and mute people. Sign language in Indonesia is Sistem Isyarat Bahasa Indonesia (SIBI) and Bahasa Isyarat Indonesia (BISINDO). BISINDO has a unique clause pattern that isSOPA (Subject, Object, Predicate, Adverbial). The clause pattern of BISINDO is just for deaf and mute people who know and understand it. Because there are some different structures between Indonesian language and BISINDO, itis neededlearning media which can translate from Indonesian language to BISINDO. Finie State Automata (FSA) is a method which is able to recognize pattern sentence classification in Indonesian language. FSA method is NSA (Non-DetermisticFinie State Automata) that is otomata with characteristics as a state. NFA is used to give introducing structure pattern sentence in Indonesian language. Sentence pattern which is produced from NFA produces eight sentences pattern which are arranged as requisites of BISINDO translation. The result of research which is experimented by sign language researchersas many as $90 \%$ can translate well and appropriate with BISINDO sentence pattern, $10 \%$ explain that it is not appropriate with translation of sentence pattern and sign language model. Based on the data, it can be known that media of BISINDO sign language learning based on web using method of translation automata can be used for learning media.
\end{abstract}

Keywords : artificial intellegence, Bisindo, sign language, automata.

\section{Latar Belakang}

Informasi dapat diterima oleh manusia melalui lima indera yaitu, indera penglihatan, indera pendengaran, indera peraba, indera penciuman, dan indera pengecapan[1]. Seorang yang tidak bisa merasakan indera pengecap (tuna wicara) dan tidak bisa merasakan indera pendengar (tuna rungu)[2]. Kaum tuna rungu dan tuna wicara (kaum difabel) berkomunikasi dengan bahasa isyarat. Di Indonesia ada dua bahasa isyarat, yaitu Bahasa Isyarat Indonesia (BISINDO) dan Sistem Isyarat Bahasa Indonesia (SIBI)[3]. Terdapat perbedaan dalam kedua bahasa isyarat tersebut. Perbedaannya yaitu gerakan isyarat bahasa, pola kalimat isyarat dan pengakuan bahasa isyarat oleh pemerintah. Asal bahasa isyarat bisindo yaitu bahasa ibu atau bahasa alami dari kaum tuna rungu, sedangkan bahasa isyarat sibi berasal dari pemerintah yang membuat[4]. Perbedaan bahasa isyarat ini membuat kalangan kaum difabel tidak bisa menerima adanya sibi sebagai bahasa isyarat nasional dan tidak diakuinya bisindo sebagai bahasa nasional yang merupakan bahasa alami dari bahasa isyarat Indonesia[5].

Perbedaan pola kalimat bisindo dan pola kalimat bahasa indonesia menyebabkan sulitnya untuk mengerti dan memahami bahasa isyarat bisindo. Pola kalimat bisindo yaitu Subyek, Obyek, Predikat, Keterangan (SOPK) yang membuat kaum normal yang akan belajar bahasa isyarat bisindo kesulitan[6]. Metode yang digunakan untuk mengubah pola kalimat yaitu automata. Automata merupakan sebuah metode yang dapat mengenali sebuah kalimat COMPILER 
seperti menerima (input) dapat diberi suatu rule / aturan tentang proses untuk dan menghasilkan output yang kita inginkan[7].

Penelitian media pembelajaran bahasa isyarat bisindo terdapat penterjemah dari bahasa indonesia ke bisindo sehingga memudahkan kaum difabel dan kaum normal untuk belajar bahasa isyarat bisindo dan sebaliknya. Metode terjemah yang digunakan yaitu metode automata menggunakan teknik Finite State Automata (FSA). Teknik FSA merupakan teknik untuk mengetahui sebuah proses terjemah dari mulai state awal hingga proses yang akan menghasilkan output berupa hasil terjemah bisindo.

\section{Metodologi Penelitian}

\subsection{Tinjauan Literatur}

Kajian literatur membahas tentang sistem dengan materi yang akan menjadi bahan pokok untuk melengkapi sistem. Kajian literatur membahas tentang bisindo dan metode terjemah bahasa. Metode terjemah yang digunakan adalah metode automata.

\subsubsection{Bisindo}

Pola kalimat bisindo yaitu SOPK[6]. Pola kalimat bisindo didapat dari buku bahasa isyarat yogyakarta. buku bahasa isyarat yoyakarta merupakan hasil penelitian yang dilakukan oleh adhi kusumo bharoto. Contoh susunan pola kalimat bahasa isyarat dalam ejaan yaitu : adhi $(\mathrm{S})$ ayam $(\mathrm{O})$ makan $(\mathrm{P})$, ejaan tersebut dikutip dari kamus bahasa isyarat Yogyakarta. Tidak wajarnya susunan pola kalimat tersebut merupakan bahasa alami dari bahasa isyarat bisindo. Berikut merupakan contoh abjad dari bahasa isyarat bisindo ditunjukkan Gambar 1 .

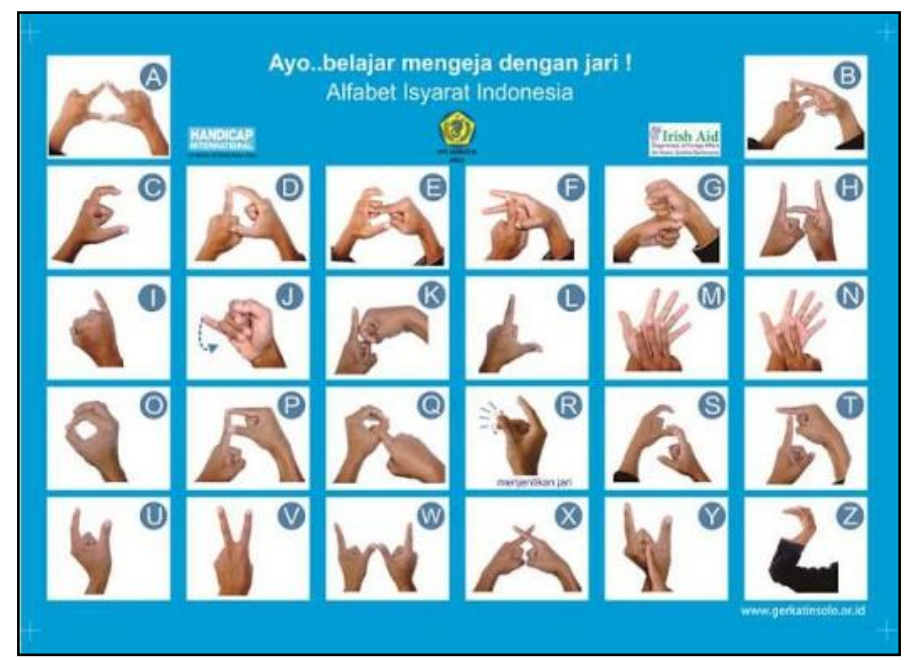

Gambar 1 Abjad Dalam Bisindo

Abjad bahasa isyarat bisindo sama seperti bahasa indonesia yang berawalan dari A dan berakhiran dengan $\mathrm{Z}$. Abjad dalam bisindo lebih menggunakan dua tangan dan menghasilkan kode atau isyarat abjad yang lebih jelas. Berikut merupakan contoh nominal dari bahasa isyarat bisindp dapat dilhat di Gambar 2 . 


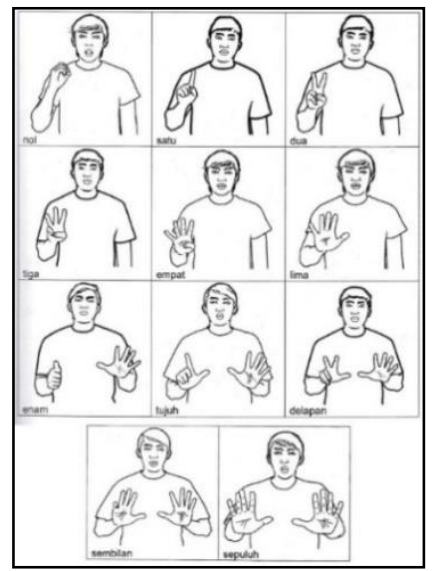

Gambar 2. Nominal Dalam Bisindo

Pembelajaran bahasa isyarat bisindo untuk kaum difabel saat ini masih mengggunakan metode manual dan hanya menggunakan media buku. Disekolah SLB tidak mempelajari bahasa isyarat khusus. Di SLB mempelajari tentang mata pelajaran biasa seperti matematika, bahasa indoonesia, IPA, IPS, dll tanpa menggunakan bahasa isyarat sebagai alat komunikasi, para kaum difabel yang ada di SLB menggunakaan bahasa oral, bahasa oral merupakan bahasa yang membca gerakan bibir dan ekspresi wajah lawan bicara[8]. Tidak semua para penyandang difabel saat belajar disekolah menggunakan bahasa oral tetapi juga ada yang mengganakan bahasa isyarat bisindo. Berikut merupakan contoh kalimat dalam bahasa isyarat bisindo dapat dilihat pada Gambar 3. Berdasarkan Gambar 3. diketahui bahwa bahasa isyarat tersebut menunjukan kalimat "Adhi Nama Saya". Susunan pola kalimat tersebut merupakan susunan pola kalimat bisindo yaitu SOPK.

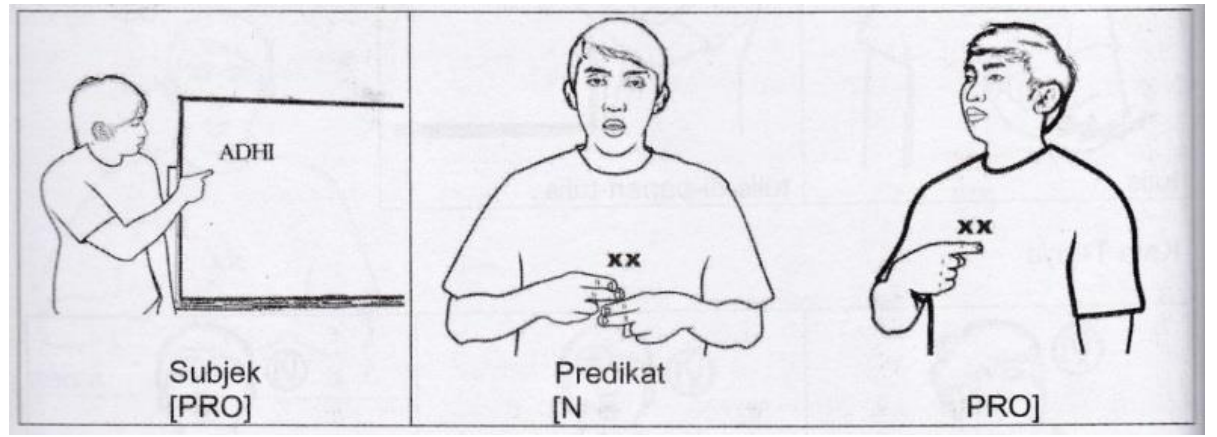

Gambar 3. Contoh Bahasa Isyarat

\subsubsection{Automata}

Automata adalah mesin abstrak yang dapat mengenali (recognize), menerima (accept), atau membangkitkan (generate) sebuah kalimat dalam bahasa tertentu[7]. Teori bahasa membicarakan bahasa formal (formal language), terutama untuk kepentingan perancangan kompilator (compiler) dan pemroses naskah (text processor). Bahasa formal adalah kumpulan kalimat. Semua kalimat dalam sebuah bahasa dibangkitkan oleh sebuah tata bahasa (grammar) yang sama. Sebuah bahasa formal bisa dibangkitkan oleh dua atau lebih tata bahasa berbeda.

Finite State Automata (FSA) adalah model matematika dari sebuah system dengan input dan output yang terdiri dari sejumlah berhingga state dan fungsi-fungsi transisi yang menyajikan perubahan state didefisinikan juga sebagai pasangan lima (5) tupel $\left(\mathrm{Q}, \sum, \delta, \mathrm{S}\right.$, 
F) mekanisme kerja dapat diaplikasikan pada : lift, text editor, analisa leksial (pada proses compile) dan parity[9].

Dimana :

1. Q : Himpunan hingga state

2. $\sum$ : Himpunan hingga simbol input

3. $\delta$ : Fungdi transisi, menggambarkan transisi state FSA akibat pembacaan input.

4. S : State awal.

5. F : State Akhir

Menurut Thomas Anung Basuki[10], FSA merupakan salah satu mesin pengenal pada bahasa kelas sederhana. Contoh yang akan diberikan untuk Diagram FSA yaitu tentang pemenggalan suku kata menggunakan metode FSA. Contoh kasus ini diperoleh dari[11] dengan judul Aplikasi Konversi Teks Menjadi Suara dengan Meggunakan Metode Penggal Kata Finite State Automata (FSA). FSA yang digunakan dirancang menjadi tiga tingkatan.

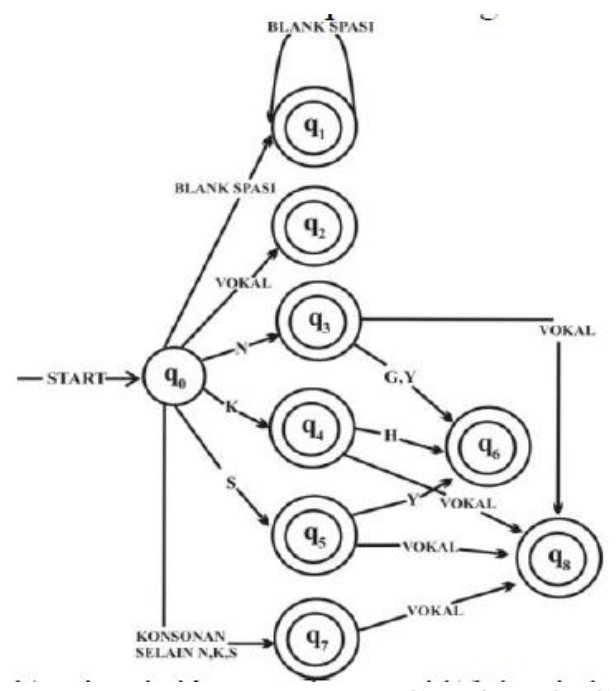

$$
\begin{aligned}
& \text { Keterangan: } \\
& q_{0}=\text { status awal } \\
& q_{1}=\text { status awal } \\
& q_{2}=\text { mengenali vokal } \\
& q_{3}, q_{4}, q_{5}, q_{7}=\text { mengenali konsonan } \\
& q_{6}=\text { mengenali konsonan yang terdiri dari } 2 \\
& \text { huruf } \\
& q_{8}=\text { mengenali konsonan - vokal }
\end{aligned}
$$

\section{Gambar 4. Contoh FSA Tingkat Pertama}

Pada tingkat pertama yang akan dikenali pada pola-pola: V, K atau VK. Hasil pengenalan FSA tingkat pertama akan menjadi masukkan pada tingkat berikutnya(Gambar 4). Pada hasil tingkatan kedua, terlihat bahwa pola suku kata VKK, KVKK, dan KKVKK belum bisa dikenali. Diperlukan FSA tingkat ketiga untuk dapat mengenali pola suku kata VKK, KVKK, dan KKVKK. Berikut contoh dari diagram FSA untuk mengenali bahasa regular. Hasil pada FSA tingkatan pertama dapat menjadi masukan pada transisi FSA tangkat kedua. Berikut FSA tingkat kedua dapat dilihat di Gambar 5. 

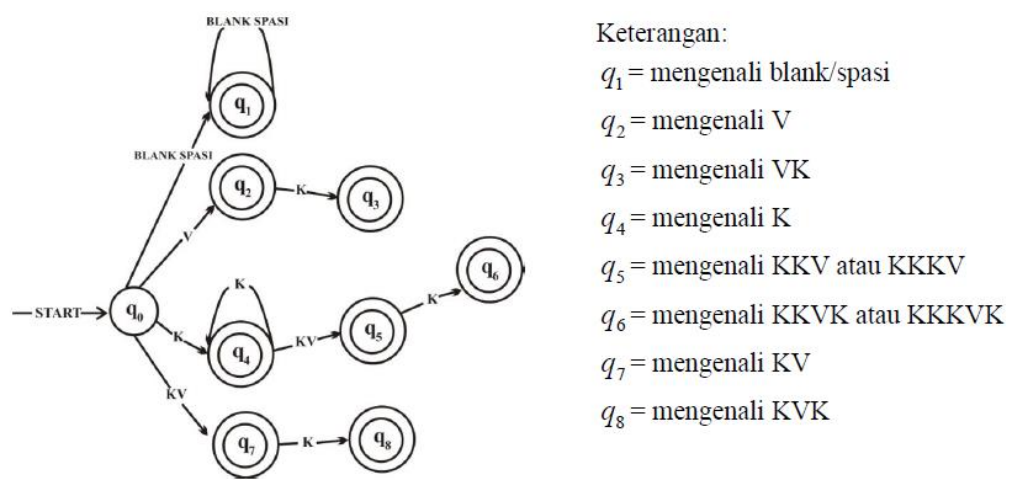

Gambar 5. Contoh FSA Tingkat Kedua

Pada FSA tingkatan kedua dapat menjadi masukan pada FSA tingkatan ketiga. FSA tingkat ketiga dapat dilihat di Gambar 6.

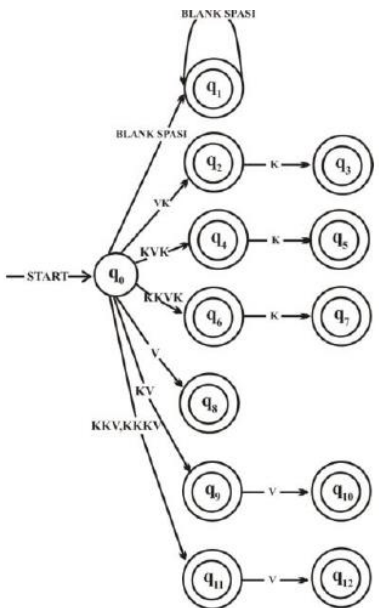

$$
\begin{aligned}
& \text { Keterangan: } \\
& q_{1}=\text { mengenali blank/spasi } \\
& q_{2}=\text { mengenali VK } \\
& q_{3}=\text { mengenali VKK } \\
& q_{4}=\text { mengenali } \mathrm{KVK} \\
& q_{5}=\text { mengenali } \mathrm{KVKK} \\
& q_{6}=\text { mengenali } \mathrm{KKVK} \\
& q_{7}=\text { mengenali } \mathrm{KKVKK} \\
& q_{8}=\text { mengenali } \mathrm{V} \\
& q_{9}=\text { mengenali } \mathrm{KV} \\
& q_{10}=\text { mengenali } \mathrm{KVV} \\
& q_{11}=\text { mengenali KKV/KKKV } \\
& q_{12}=\text { mengenali } \mathrm{KKVV} / \mathrm{KKKVV}
\end{aligned}
$$

Gambar 6. Contoh FSA Tingkat Ketiga

\subsection{Perancangan Sistem}

Metode pengembangan perangkat lunak yang digunakan yaitu waterfall / air terjun yang dikembangkan oleh pressman dan metode pengembangan multimedia yang dikembangkan oleh sutopo, Metode Pengembangan perangkat lunak (waterfall) memiliki tahap-tahap sebagai berikut yaitu analisis, desain sistem, penulisan kode (coding), pengujian program, perawatan (maintance). Metode waterfall yang digunakan dalam penelitian hanya sampai pada tahap pengujian sistem. Selain menggunakan metode pengembangan perangkat lunak, juga menggunakan metode pengembangan multimedia untuk mengolah video yang akan dimasukkan ke dalam database. Metode pengembangan multimedia yang dikembangkan oleh sutopo meliputi konsep, desain, material collecting, Assembly (Pembuatan), testing, distribution. Metode pengembangan multimedia yang dalam penelitian ini hanya sampai pada tahap testing.

Metode penelitian yang dilakukan meliputi pengumpulan data, perancangan sistem dan pengujian secara black box. Tahap pengujian yang dilakukan yaitu alpha test dan beta test. Pada tahap pengumpulan data akan dibahas beberapa tahap yaitu studi pustaka, observasi dan wawancara. Pada tahap perancangan sistem ada beberapa metode yang digunakan, yaitu Metode Pengembangan perangkat lunak (waterfall) dan Metode pengembangan multimedia. Flowchart alur terjemah pada penelitian ini ditunjukkan pada Gambar 7. 


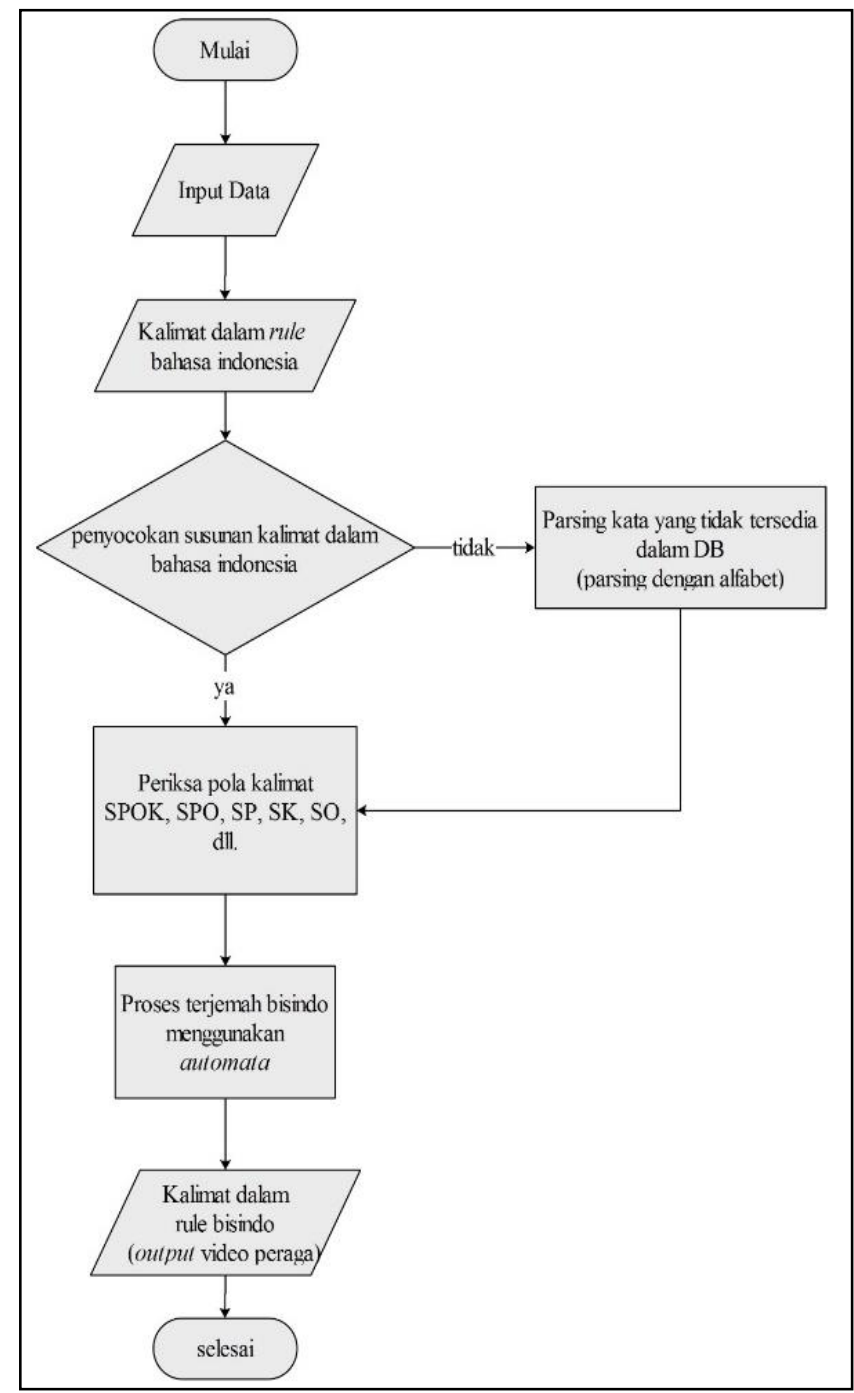

Gambar 7. Flowchart Alur Terjemah

Pada Gambar 7. Flowchart Alur Terjemah dapat dijelaskan bahwa tahap pertama user menginputkan kalimat dalam bahasa indonesia. Sistem memiliki algoritma untuk mencocokkan pola kalimat yang diinputkan. Selain mencocokkan pola kalimat, sistem juga akan memeriksa keberadaan susunan kalimat berupa kata yang ada didalam database. Jika kata tidak ada didalam database maka, kata tersebut akan dipisah / parsing sesuai susunan kata (abjad). Hasil penyocokan kata dan parsing akan diterjemahkan sesuai dengan rule bahasa isyarat bisindo.

Algoritma pencocokan pola kalimat pertama dilakukan pemeriksaan keberadaan susunan kalimat berupa kata yang ada didalam database. Jika kata tidak ditemukan didalam database maka, kata tersebut akan dipisah / parsing sesuai susunan kata (abjad). Hasil penyocokan kata dan parsing akan diterjemahkan sesuai dengan rule bahasa isyarat bisindo.

\subsection{Proses Parsing dan Pembalikan Pola Kalimat Bisindo}

Pada bagian ini akan diberikan contoh proses otomata yang dilakukan untuk menterjemahkan dari bahasa indonesia ke bahasa isyarat bisindo. 


\section{a. Metode Parsing}

Parsing dapat dilakukan secara top-down maupun bottom-up, masing-masing memiliki kelebihan dan kekurangannya sendiri. Top-down parsing tidak dapat menangani grammar dengan left-recursion, sedangkan bottom-up parsing tidak dapat menangani grammar dengan empty production. Karena itu metode parsing yang terbaik ialah yang dapat menggabungkan kedua cara.

Contoh parsing yang digunakan:

Juka diketahui kata "tangkap"

$\rightarrow$ kata tangkap di input kan.

$\rightarrow$ sistem akan mengecek atau memeriksa keberadaan kata "tangkap" kedalam database

$\rightarrow$ jika kata "tangkap" terdapat didalam database maka akan diterjemahkan langsung kedalam bahasa isyarat bentuk video

$\rightarrow$ jika kata "tangkap" tidak ditemukan dalam database maka kata "tangkap" akan diparsing menjadi seperti ini : "t a n g k a p" dan akan diterjemahkan per karakter. Karakter yang diambil dari kamus alfabet yaitu kamus yang terdapat pada database dari kumpulan video alfabet dari A-Z. Setelah diparsing dan dicocokkan dengan database karakter alfabet akan diterjemahkan sesuai urutan dan ditampilkan berupa video.

\section{b. Pushdown Automata (PDA)}

Pushdown automata (PDA) merupakan jenis otomata yang menggunakan stack atau tumpukan untuk mempresentasikan tata Bahasa bebas konteks (context - free grammar). Yang dimaksud Bahasa bebas konteks adalah tatabahasa yang tidak memiliki batasan terhadap hasil produksinya.

Implementasi yang ada didalam sistem yang dibangun yaitu untuk membaca jenis kalimat yan diinputkan. Jenis kalimat yang dimaksud adalah pola kalimat Bahasa Indonesia yaitu SPO, SPOK, SPK, SP dalam sistem hanya menggunakan pola kalimat tersebut. Contoh jika diketahui suatu kalimat dengan pola SPOK seperti yang ditunjukkan pada Gambar 8.

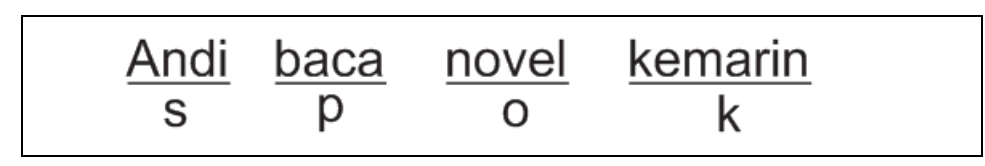

Gambar 8. Contoh Kalimat SPOK

Langkah-langkah pengimplementasian pushdown automata (PDA) adalah sebagai berikut:

Langkah 1: Kalimat tersebut akan dilakukan pencocokan pola kalimat dalam database. Gambar 9. menunjukkan pola kalimat yang telah diketahui setelah proses pengecekan kedalam database.

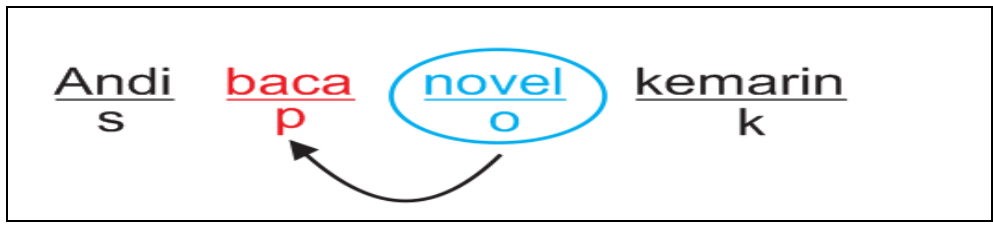

Gambar 9. Contoh kalimat SPOK

Langkah 2: Setelah diketahui pola kalimatnya, selanjutnya kalimat tersebut akan dikonversikan kedalam bentuk susunan kalimat bahasa isyarat Bisindo yaitu SOPK. Hasil konversi kalimat menggunakan pla kalimat Bisindo ditunjukkan dalam Gambar 10. Jika kata 
tidak ada didalam database maka, kata tersebut akan dipisah / parsing sesuai susunan kata (abjad).

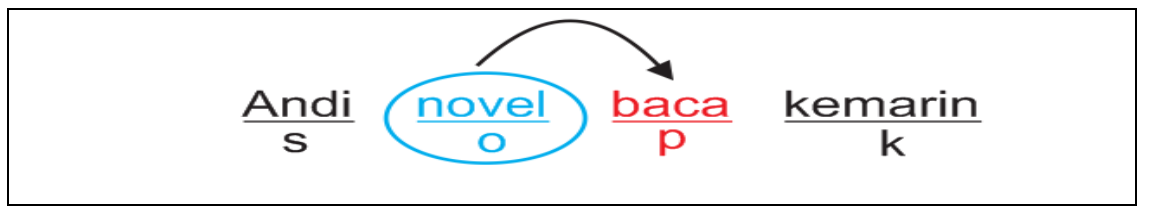

Gambar 10. Contoh Kalimat SOPK

Langkah 3: Selanjutnya kalimat tersebut akan diterjemahkan kedalam video peraga bahasa isyarat Bisindo sesuai susunan kalimat yang telah tersusun.

\section{Hasil dan Pembahasan}

Hasil penelitian menunjukkan bahwa telah menerapkan konsep automata sebagai metode terjemah bahasa isyarat bisindo dengan teknik Finite State Automata (FSA). Hasil terjemah dengan pola kalimat SPOK menjadi SOPK, hasil terjemah menunjukkan kesesuaian dari pola kalimat bisindo.

\subsection{Finite State Automata (FSA)}

FSA berfungsi untuk melihatkan alur terjemah bahasa indonesia ke bahasa isyarat bisindo. Menurut Thomas Anung Basuki[11], FSA merupakan salah satu mesin pengenal pada bahasa kelas sederhana. Penggunaan FSA sesuai untuk pemenggalan kata, kalimat dan pengenalan video melalui inputan berupa teks. FSA merupakan mesin abstrak yang mampu mendeteksi kata atau kalimat dalam bahasa indonesia dan akan diterjemahkan dalam aturan atau rule kalimat bisindo.

Salah satu cara yang dianjurkan dalam menuliskan FSA yaitu dengan menggunakan transition (diagram transisi), yaitu berupa graf dengan arah simbol - symbol transisinya. Secara Formal FSA dinyatakan oleh lima tupel, dimana :

$\mathrm{M}=\left(\mathrm{Q}, \sum, \delta, \mathrm{S}, \mathrm{F}\right)$

$\mathrm{Q}=$ himpunan state / kedudukan

$\sum=$ himpunan symbol input / masukan / abjad / karakter

$\delta=$ fungsi transisi

$\mathrm{S}=$ state awal / kedudukan awal (initial state)

$\mathrm{F}=$ himpunan state akhir

Menurut [12,13,14] FSA terdiri atas :

Determistic Finite State Automata (DFA) merupakan otomata hingga dengan ciri khas berupa dari suatu state ada tempat satu state berikutnya untuk setiap symbol masukan yang diterima. DFA terdiri atas :

a. Himpunan keadaan (state) yang dilambangkan dengan Q.

b. Himpunan alfabet (alphabet) atau himpunan simbol input, dilambangkan dengan $\sum$.

c. Satu keadaan (state) awal, dilambangan dengan S.

d. Himpunan keadaan (state) akhir, dilambangkan dengan F.

e. Fungsi transisi dilambangkan dengan $\delta$.

Non-Determistic Finite State Automata (NFA) merupakan otomata hingga dengan ciri khas berupa dari suatu state ada 0,1 atau lebih state berikutnya untuk setiap simbol masukan yang diterima. NFA terdiri atas :

a. Himpunan keadaan (state) yang dilambangkan dengan Q.

b. Himpunan alfabet (alphabet) atau himpunan simbol input dilambangkan dengan $\sum$.

c. Satu keadaan (state) awal, dilambangkan dengan S. 
d. Himpunan keadaan (state) akhir, dilambangkan dengan F.

e. Relasi transisi dilambaangkan dengan $\delta$.

FSA memiliki terdiri atas 2 yaitu NFA dan DFA, FSA yang digunakan untuk mengenali pola kalimat bahasa indonesia menggunakan Non-Determistic Finite State Automata (NFA). NFA dipilih untuk digunakan dalam mengenali pola kalimat karena memiliki state yang lebih dari 0 dan 1. Berikut merupakan NFA dari pengenalan pola kalimat dalam bahasa indonesia yang akan digambarkan dalam diagram transisi NFA. Diagram transisi NFA dapat dilihat di Gambar 10.

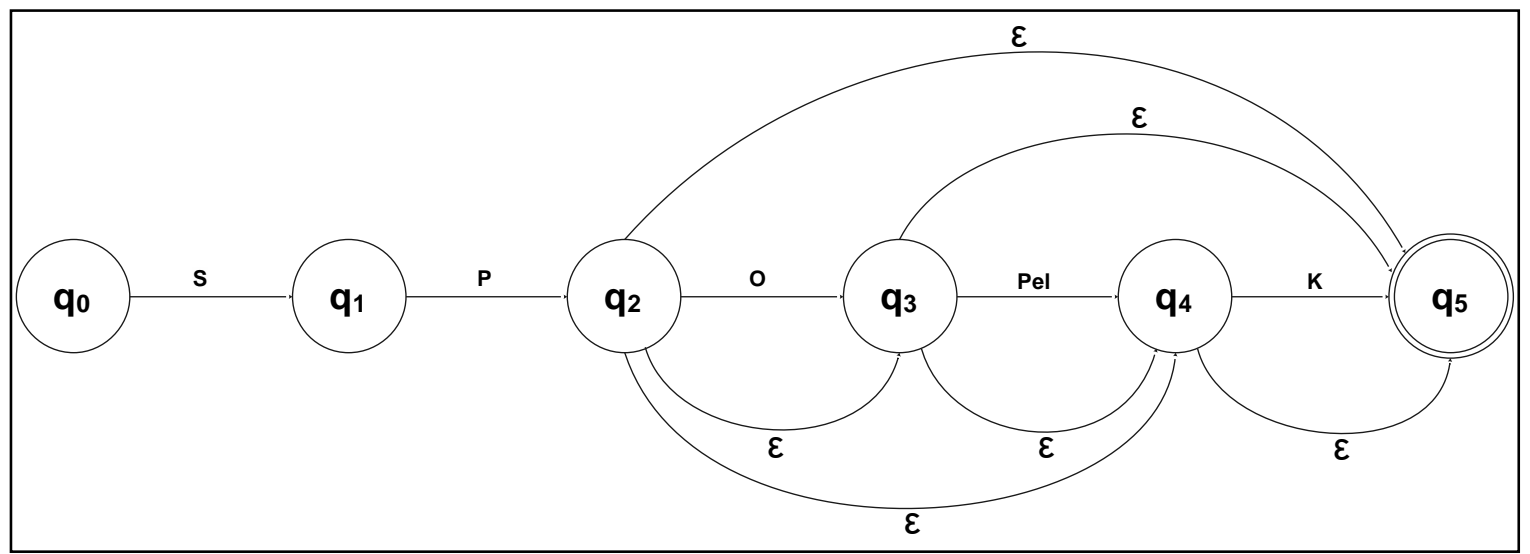

Gambar 10. Diagram transisi NFA

NFA memiliki karakteristik sebagai berikut :

$\mathrm{Q}=\{\mathrm{q} 0, \mathrm{q} 1, \mathrm{q} 2, \mathrm{q} 3, \mathrm{q} 4, \mathrm{q} 5\}$

$\sum=\{\mathrm{S}, \mathrm{P}, \mathrm{O}, \mathrm{Pel}, \mathrm{K}\}$

$\mathrm{S}=\{\mathrm{q} 0\}$

$\mathrm{F}=\left\{\mathrm{q}_{5}\right\}$

Diagram transisi pada Gambar 10. menghasilkan 8 (delapan) pola kalimat, yaitu :

a. Pola kalimat S-P (Subyek, Predikat)

$$
\mathbf{q}_{0} \stackrel{S}{\mathrm{~S}}, \mathbf{q}_{1} \stackrel{\mathrm{P}}{\longrightarrow}, \mathbf{q}_{2} \stackrel{\varepsilon}{\varepsilon}, \mathbf{q}_{5}
$$

b. Pola kalimat S-P-O (Subyek, Predikat, Obyek)

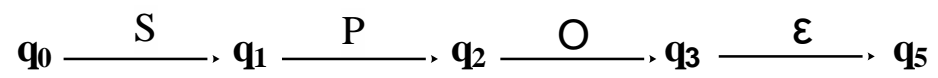

c. Pola kalimat S-P-Pel (Subyek, Predikat, Pelengkap)

$$
\mathbf{q}_{0} \stackrel{S}{S}, \mathbf{q}_{1} \stackrel{\mathrm{P}}{\longrightarrow}, \mathbf{q}_{2} \stackrel{\varepsilon}{\boldsymbol{\varepsilon}}, \mathbf{q}_{3} \stackrel{\mathrm{Pel}}{\longrightarrow}, \mathbf{q}_{4} \stackrel{\varepsilon}{\longrightarrow}, \mathbf{q}_{5}
$$

d. Pola kalimat S-P-O-Pel (Subyek, Predikat, Obyek, Pelengkap)

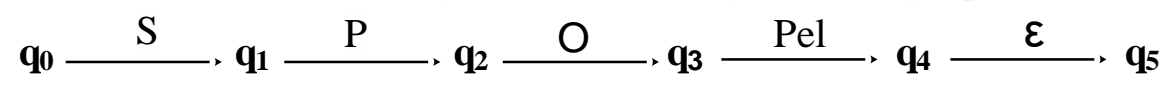

e. Pola kalimat S-P-O-Pel-K (Subyek, Predikat, Obyek, Pelengkap, Keterangan)

$$
\mathbf{q}_{0} \stackrel{\mathrm{S}}{\longrightarrow}, \mathbf{q}_{1} \stackrel{\mathrm{P}}{\longrightarrow}, \mathbf{q}_{2} \stackrel{\mathrm{O}}{\mathrm{O}}, \mathbf{q}_{3} \stackrel{\mathrm{Pel}}{\longrightarrow}, \mathbf{q}_{4} \stackrel{\mathrm{K}}{\longrightarrow}, \mathbf{q}_{5}
$$


f. Pola kalimat S-P-K (Subyek, Predikat, Keterangan)

$$
\mathbf{q}_{0} \stackrel{\mathrm{S}}{\longrightarrow}, \mathbf{q}_{1} \stackrel{\mathrm{P}}{\longrightarrow}, \mathbf{q}_{2} \stackrel{\varepsilon}{\varepsilon}, \mathbf{q}_{4} \stackrel{\mathrm{K}}{\longrightarrow}, \mathbf{q}_{5}
$$

g. Pola kalimat S-P-O-K (Subyek, Predikat, Obyek, Keterangan)

$\mathbf{q}_{0} \stackrel{\mathrm{S}}{\longrightarrow}, \mathbf{q}_{1} \stackrel{\mathrm{P}}{\longrightarrow}, \mathbf{q}_{2} \stackrel{\mathrm{O}}{\mathrm{O}}, \mathbf{q}_{3} \stackrel{\varepsilon}{\longleftarrow}, \mathbf{q}_{4} \stackrel{\mathrm{K}}{\longrightarrow}, \mathbf{q}_{5}$

h. Pola kalimat S-P-Pel-K (Subyek, Predikat, Pelengkap, Keterangan)

$\mathbf{q}_{0} \stackrel{S}{\longrightarrow}, \mathbf{q}_{1} \stackrel{\mathrm{P}}{\longrightarrow}, \mathbf{q}_{2} \stackrel{\varepsilon}{\varepsilon}, \mathbf{q}_{3} \stackrel{\mathrm{Pel}}{\longrightarrow}, \mathbf{q}_{4} \stackrel{\mathrm{K}}{\longrightarrow}, \mathbf{q}_{5}$

\subsection{Tata Bahasa / Grammar (Context Free Grammar)}

Grammar didefnisikan sebagai pasangan 4 (empat) tuple : Vt, Vn, S, dan P dan dituliskan sebagai G(Vt, Vn, S, P) [12]. Dapat dideskripsikan sebagai berikut:

$\mathrm{G} \quad$ : Vt, Vn, S, P

Vt : Himpunan simbol-simbol terminal (alfabet) $\rightarrow$ kamus

Vn : Himpunan simbol-simbol non terminal

S : Simbol awal (atau simbol start)

$\mathrm{P}$ : Himpunan produksi

Tata bahasa dalam automata memberikan aturan pada pola kalimat bahasa indonesia dengan 8 (delapan) pola kalimat.

Berikut merupakan 4 (empat) tuple yang dapat dituliskan :

$\mathrm{G}=\{\mathrm{Vt}, \mathrm{Vn}, \mathrm{S}, \mathrm{P}\}$

Vt : $\{$ alfabet / Kamus $\}$

Vn : $\{$ Kalimat, Subyek, Predikat, Obyek, Pelengkap, Keterangan $\}$

$\mathrm{S}$ : Kalimat

$\mathrm{P} \quad:$ Kalimat $\rightarrow \mathrm{S}-\mathrm{P}$

Kalimat $\rightarrow$ Subyek - Predikat - Obyek

Kalimat $\rightarrow$ Subyek - Predikat - Pelengkap

Kalimat $\rightarrow$ Subyek - Predikat - Obyek - Pelengkap

Kalimat $\rightarrow$ Subyek - Predikat - Obyek - Pelelengkap - Keterangan

Kalimat $\rightarrow$ Subyek - Predikat - Keterangan

Kalimat $\rightarrow$ Subyek - Predikat - Obyek - Keterangan

Kalimat $\rightarrow$ Subyek - Predikat - Pelengkap - Keterangan

Berikut merupakan contoh dari setiap kategori kata dari pola kalimat

$\mathrm{S}$ = Saya, Adinda, Ayah, Ibu, Dia, Kamu, Kita ...

$\mathrm{P} \quad=$ Makan, Tidur, Pergi, Main, Pulang, Masuk ...

$\mathrm{O}=$ Bebek, Bunga, Komputer, Handphone ...

Pel $=$ Enak, Lezah, Mahal sekali, Kurang lezat ...

$\mathrm{K}$ = Malam, Siang, Pasar, Sekolah, Kantor, Terlambat ... 
Proses penterjemahan dari Bahasa Indonesia ke system Bahasa isyarat bisindo ditunjukkan dalam Pseudocode pada Gambar 11.

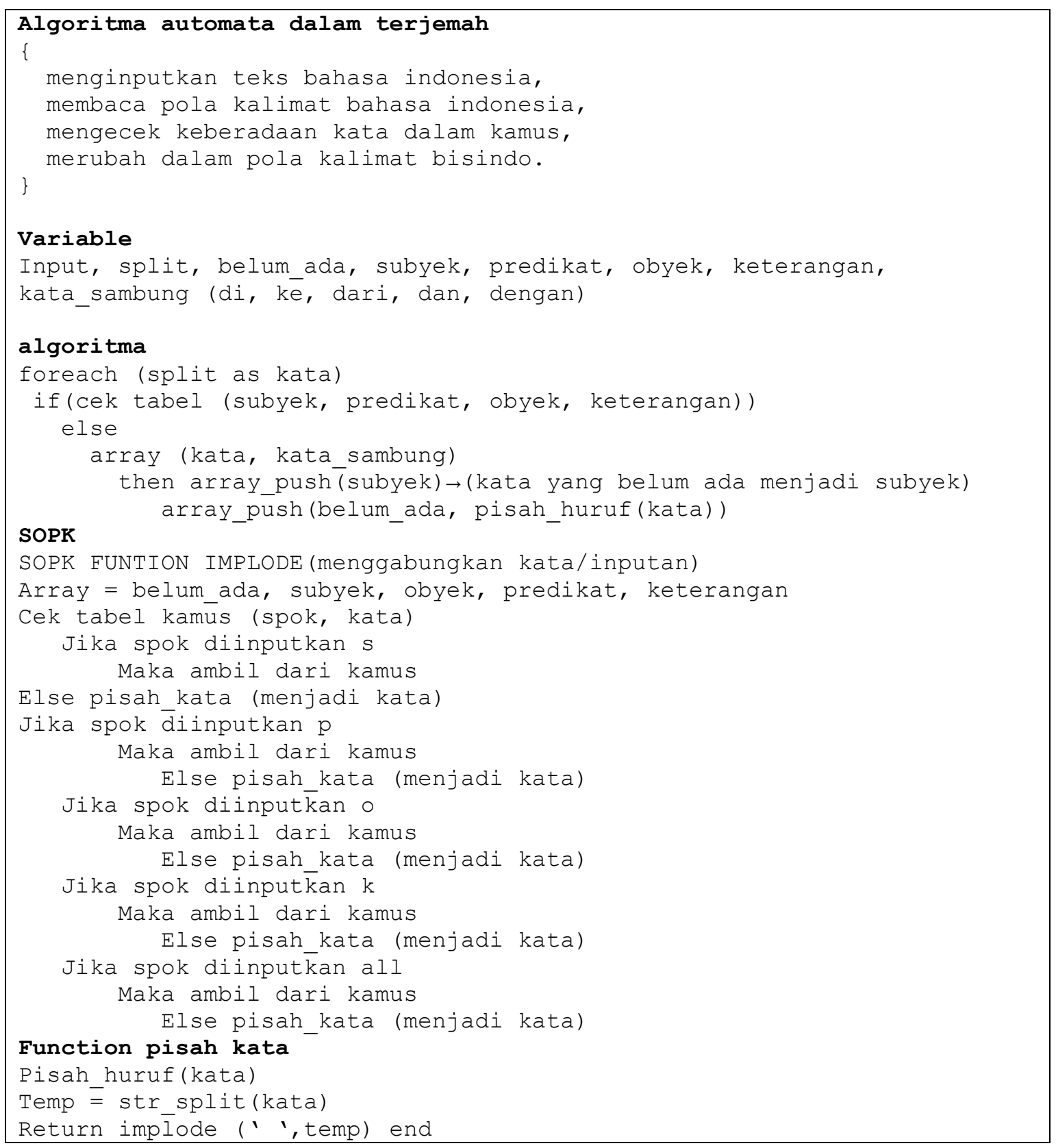

Gambar 11. Pseudocode Halaman Terjemah

Tabel 1. Hasil Pengujian Beta Test

\begin{tabular}{|c|c|c|c|c|c|}
\hline No & Pola Kalimat & $\begin{array}{c}\text { Jumlah } \\
\text { kalimat }\end{array}$ & Sesuai & $\begin{array}{c}\text { Tidak } \\
\text { Sesuai }\end{array}$ & $\begin{array}{c}\text { Kesesuaian Hasil } \\
(\boldsymbol{\%})\end{array}$ \\
\hline 1 & S & 30 & 29 & 1 & 96.67 \\
\hline 2 & P & 30 & 29 & 1 & 96.67 \\
\hline 3 & O & 30 & 28 & 2 & 93.33 \\
\hline 4 & K & 30 & 30 & 0 & 100 \\
\hline
\end{tabular}




\begin{tabular}{|c|c|c|c|c|c|}
\hline 5 & NOMINAL & 10 & 10 & 0 & 100 \\
\hline 6 & SP & 30 & 29 & 1 & 96.67 \\
\hline 7 & SO & 30 & 30 & 0 & 100 \\
\hline 8 & SK & 30 & 25 & 5 & 83.33 \\
\hline 9 & SPO & 30 & 22 & 8 & 73.33 \\
\hline 10 & SPK & 30 & 24 & 6 & 80 \\
\hline 11 & SPOK & 30 & 23 & 7 & 76.67 \\
\hline & $\begin{array}{c}\text { TOTAL } \\
\text { KESELURUHAN }\end{array}$ & 310 & 279 & 31 & \\
\hline & $\begin{array}{c}\text { TOTAL } \\
\text { KESELURUHAN } \\
\text { ALAM PERSEN }(\%)\end{array}$ & $100 \%$ & $90 \%$ & $10 \%$ & \\
\hline
\end{tabular}

\section{Pengujian Sistem}

Pengujian yang dilakukan oleh Adhi Kusumo Bharoto selaku peneliti bahasa isyarat bisindo yang ada di Yogyakarta. Pengujian dilakukan untuk mengetahui ketepatan atau akurasi terjemah bahasa indonesia ke bahasa isyarat bisindo melalui inputan atau masukkan kata dan kalimat sehingga diproses oleh sistem mengenai keakuratan dalam merubah pola kalimat dan ketepatan dalam peraga bahasa isyarat bisindo. Berikut merupakan hasil dari pengujian beta test yang dilakukan oleh Adhi Kusumo Bharoto. Hasil pengujian dapat dilihat di Tabel 1.

Hasil pengujian validasi beta test dapat diperoleh kesimpulan bahwa responden menguji kata dan susunan kata berupa kalimat (SP (30), SO (30), SK(30), SPK(30), SPO(30), SPOK(30), S(30), P(30), O(30), K(30) dan Nominal(10)) total sejumlah 279 sepakat dan 31 tidak sepakat dari total pernyataan kata dan kalimat sebanyak 310 mengetahui presentase dari masing-masing pilihan jawaban dapat digunakan rumus sebagai berikut :

$$
\text { Presentase }=\frac{\text { Skor }}{\text { Jumlah_Pertanyaan } * \text { Jumlah_Responden }} * 100 \%
$$

Prosentase hasil penilaian yang memberikan jawaban Sepakat dan tidak sepakat adalah sebagai berikut :

$\begin{array}{llll}\text { Sepakat } & =279 / 310 * 100 \% & = & 90 \% \\ \text { Tidak Sepakat } & =31 / 310 * 100 \% & = & 10 \%\end{array}$

Hasil penelitian ini menunjukkan bahwa sepakat $90 \%$ untuk kamus perkata,nominal,abjad dan pembalikan pola kalimat dalam bahasa isyarat bisindo. Sedangkan tidak sepakat sebesar $10 \%$ merupakan ketidaksesuain untuk kata khusus dalam kalimat / pola kalimat dalam bahasa isyarat bisindo seperti kata hubung ke, di, dan, dengan, dari, akan dan kata morfologi seperti kata yang mewakili ekspresi wajah, kata yang mewakili ekspresi wajah tidak perlu seperti contoh kata "sangat".

\section{Kesimpulan}

Kesimpulan yang didapat dari penelitian yaitu telah menerapkan konsep automata sebagai proses penterjemah dari kalimat bahasa indonesia ke bahasa isyarat bisindo. Sistem 
penterjemah bahasa isyarat dapat diakses di http://bisindo.awginc.web.id. Teknik Automata yang sesuai untuk mengubah atau menterjemahkan teks bahasa indonesia ke bahasa isyarat bisindo adalah Finite State Automata (FSA). Hasil terjemah dari bahasa indonesia ke bahasa isyarat bisindo menghasilkan pola kalimat bisindo yaitu SOPK (Subyek, Obek, Predikat dan Keterangan). Proses terjemah dilakukan dengan teknik FSA yaitu teknik yang mampu mengenali dan mengubah suatu kondisi kalimat. Kondisi kalimat telah ditentukan, yaitu inputan sebuah kalimat dalam bahasa indonesia (SPOK) dan diproses ke dalam pola kalimat bahasa isyarat bisindo (SOPK). Fungsi dari FSA yaitu mengenali pola inputan kalimat dan mengubah ke dalam pola kalimat bisindo. Pengujian mendapatkan hasil kesesuaian kata dan pola kalimat sebesar $90 \%$ dari hasil pengujian yang dilakukan oleh adhi selaku peneliti bahasa isyarat bisindo. $10 \%$ prosentase yang tidak sesuai merupakan ketidaksesuaian dalam menterjemahan dan terdapat beberapa kamus yang tidak sesuai dengan bahasa isyarat bisindo.

Beberapa saran yag dapat dipertimbangkan untuk pengembangan dimasa mendatang yaitu penambahan fitur untuk membaca gerakan tangan atau isyarat tangan untuk menjadi sebuah teks dalam bahasa indonesia. Pengembangan selanjutnya mampu mengenal pola kalimat yang majemuk sebagai masukkan teks untuk diterjemahkan. Kalimat majemuk yang memiliki imbuhan dan akhiran kata sehingga susunan pola kalimat menjadi sebuah kalimat yang lebih sempurna atau efektif.

\section{Daftar Pustaka}

[1] Dudung, 2015. Pengertian 6 jenis indera manusia dan fungsinya (Panca Indera). Artikel online : http://www.dosenpendidikan.com/pengertian-6-jenis-inderamanusia-dan-fungsinya-panca-indera/ diakses pada tanggal 12 Juni 2015, 11:15 WIB

[2] Howard \& Orlensky. 1994. Special Needs Education. Jakarta: Unindo Press. 1994).

[3] Gumelar, Gilang. Hafiar, Hanny. Subekti, Priyo. (2018). Bahasa Isyarat Indonesia Sebagai Budaya Tuli Melalui Pemaknaan Anggota Gerakan Untuk Kesejahteraan Tuna Rungu. Jurnal Informasi: Kajian Ilmu Komunikasi., 48(1).

[4] Bharoto, (a) 2014. Bahasa Isyarat Yogyakarta Kamus Pendamping untuk buku pedoman siswa 1 tingkat 1. Jakarta : Fakultas Ilmu Pengetahuan dan Budaya Universitas Indonesia.

[5] Bharoto, (b) 2014. Bahasa Isyarat Yogyakarta Buku Pedoman Siswa 1 tingkat 1. Jakarta : Fakultas Ilmu Pengetahuan dan Budaya - Universitas Indonesia.

[6] Bharoto, (c) Adhi Kusumo, 2015, "Pola kalimat bahasa isyarat bisindo adalah SOPK (Subyek-Obyek-Predikat-Keterangan)",Yogyakarta, 14 April 2015

[7] Sulistyo, Adi 2013. Teori Bahasa \& Otomata. Yogyakarta : Graha Buku.

[8] Rahmi, 2015, Disekolah SLB tidak mempelajari bahasa isyarat khusus. Di SLB mempelajari tentang mata pelajaran biasa seperti matematika, bahasa indoonesia, IPA, IPS, dll tanpa menggunakan bahasa isyarat sebagai alat komunikasi, para kaum difabel yang ada di SLB menggunakaan bahasa oral, bahasa oral merupakan bahasa yang membca gerakan bibir dan ekspresi wajah lawan bicara. SLB N1 Bantul, 20 November 2015.

[9] Linz, Peter. 2001. An Introduction to Formal Language and Automata. John and Bartlett Publisher.

[10]Basuki, Thomas Anung. 2000. Pengenalan Suku Kata Bahasa Indonesia Menggunakan Finite State Automata. Jurnal Integral., 5(2). 
[11] Isrokah. \& Yasin, Muhammad. 2013. Aplikasi konversi teks menjadi suara dengan menggunakan metode penggal kata finite state automata (FSA). Jurnal CYBERTECHN., 7(2).

[12]Rustamaji, 2004. Teori Bahasa dan Otomata. Program Studi Teknik Informatika, Fakultas Teknologi Industri, Universitas Pembangunan Nasional "Veteran" Yogyakarta.

[13] Suryadi, 1995. Pengantar Automata Bahasa Formal dan Kompilasi. Gunadarma, Bandung.

[14]Wahono, 2015. Theory Of Computation, Finite Automata. Diakses melalui http://romisatriawahono.net/tc pada 4 Desember 2015, 12:45 WIB. 